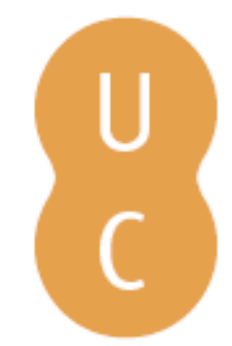

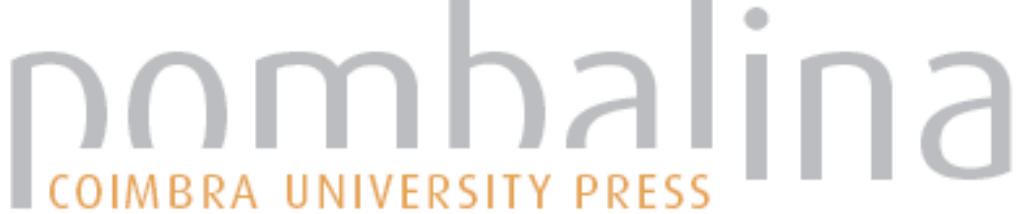

\section{Homenagem a Rómulo de Carvalho}

Autor(es): $\quad$ Providência, João da

Publicado por: Imprensa da Universidade de Coimbra

URL

persistente: URI:http://hdl.handle.net/10316.2/32274

DOI: $\quad$ DOI:http://dx.doi.org/10.14195/978-989-26-0413-8_7

Accessed : $\quad$ 26-Apr-2023 03:46:49

A navegação consulta e descarregamento dos títulos inseridos nas Bibliotecas Digitais UC Digitalis, UC Pombalina e UC Impactum, pressupõem a aceitação plena e sem reservas dos Termos e Condições de Uso destas Bibliotecas Digitais, disponíveis em https://digitalis.uc.pt/pt-pt/termos.

Conforme exposto nos referidos Termos e Condições de Uso, o descarregamento de títulos de acesso restrito requer uma licença válida de autorização devendo o utilizador aceder ao(s) documento(s) a partir de um endereço de IP da instituição detentora da supramencionada licença.

Ao utilizador é apenas permitido o descarregamento para uso pessoal, pelo que o emprego do(s) título(s) descarregado(s) para outro fim, designadamente comercial, carece de autorização do respetivo autor ou editor da obra.

Na medida em que todas as obras da UC Digitalis se encontram protegidas pelo Código do Direito de Autor e Direitos Conexos e demais legislação aplicável, toda a cópia, parcial ou total, deste documento, nos casos em que é legalmente admitida, deverá conter ou fazer-se acompanhar por este aviso.

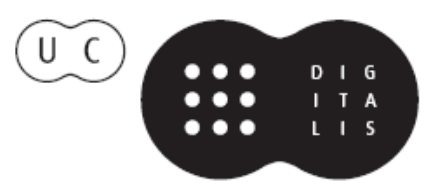


João Rui Pita

Coordenaçáo

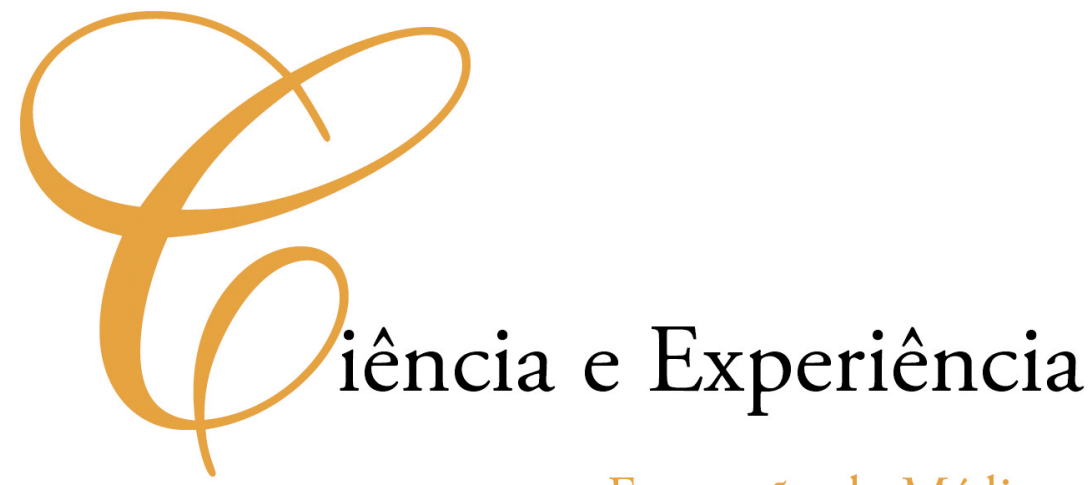

Formação de Médicos, Boticários, Naturalistas e Matemáticos

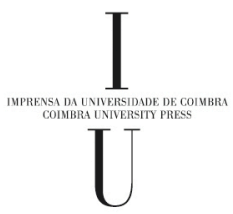

- COIMBRA 2006 
João da Providência

Departamento de Física

Faculdade de Ciências e Tecnologia da Universidade de Coimbra

\section{homenagem a Rómulo de CARVAlho}

As coisas belas, as que deixam cicatrizes na alma dos homens, por que motivo serão belas? E belas, para quê?

Põe-se o Sol porque o seu movimento é relativo. Derrama cores porque os meus olhos vêem. Mas por que será belo o pôr Sol?

E belo para quê?

Se acaso as coisas não são coisas em si mesmas, mas só são coisas quando coisas percebidas, por que direi das coisas que são belas?

E belas, para quê?

Se acaso as coisas forem coisas em si mesmas sem precisarem de ser coisas percebidas, para quem serão belas essas coisas? E belas, para quê?

Poema das coisas belas, António Gedeão

O prestígio crescente da Filosofia Newtoniana e da Física Experimental desencadeou, no sec. XVIII, uma extraordinária onda de curiosidade intelectual foco, de uma verdadeira reacção em cadeia que catalisou a difusão científica e acelerou o progresso. Em Setecentos, as sessões de 
Física Experimental constituíam uma forma de diversão pública apreciada e muito em voga. A Ciência, longe de ser uma fria especulação intelectual adquiriu uma inesperada dimensão lúdica. Obter imagens muito ampliadas, fazer pular figurinhas leves, erguer, sem esforço, corpos pesados, ou levantar os cabelos às damas, eram entretenimentos cujo palco se situava nas casas dos nobres ou nas próprias ruas das cidades. Os espíritos cultos interessavam-se vivamente pela Ciência, particularmente pela Física, sendo de assinalar a sua penetração em círculos filosóficos onde constituía tema favorito de debate.

O Autor do Poema das coisas belas não podia ficar indiferente a este período histórico tão pleno de beleza. O Professor Rómulo de Carvalho investigou-o apaixonadamente e descreveu-o de forma magistral. A valiosíssima obra sobre o século das luzes que nos legou é referência obrigatória para quantos se dedicam ao estudo desta época fascinante. Pelos seus escritos, a ela somos transportados como por magia, em viagem maravilhosa através do Tempo.

O Museu de Física é uma jóia do iluminismo que Rómulo de Carvalho admirava e amava. Investigara de forma exaustiva os seus instrumentos e a sua história, que conhecia profundamente. Quantas vezes lhe terá ocorrido a pergunta: As máquinas do Gabinete de Física, por que motivo serão belas? E belas, para quê? A merecidíssima homenagem que lhe é prestada neste lugar histórico reveste-se, por esse motivo, dum simbolismo particular. 